\title{
Bokrecension: An Active Student Participation Companion
}

\author{
Gun Sparrhoff \\ Institutionen för beteendevetenskap och lärande/Didacticum, Linköpings universitet
}

Barrineau, Sanna, Engström, Alexis \& Schnaas, Ulrike (2019). An Active Student Participation Companion. Uppsala university: Unit for Academic Teaching and Learning.

I mitt arbete som lärare, pedagogisk utvecklare och studierektor har jag ofta lite dåligt samvete för att jag inte i tillräckligt hög grad och på ett meningsfullt sätt involverar och tar till vara studenternas tankar och erfarenheter. Viljan finns, men ... Ja, det tycks alltid finnas en massa "men" i vägen. Kanske beror det på en brist på kunskap om hur man kan göra för att få till en bra studentmedverkan och inte bara en pliktskyldig studentrepresentation. Det är därför med intresse som jag har läst boken An Active Student Participation Companion.

Boken riktar sig till olika typer av utbildare (i vid bemärkelse) och studenter inom högre utbildning, både nationellt och internationellt. Av den anledningen är den skriven på engelska. Författarna riktar även en inbjudan till andra grupper såsom aktivister, pedagogiska utvecklare, doktorander, forskare och en intresserad allmänhet. Boken använder sig genomgående av akronymen ASP för Active Student Participation.

I linje med bokens intention och innehållsliga idé är boken samförfattad av två personer som nyligen har varit studenter (Sanna Barrineau och Alexis Engström) samt en pedagogisk utvecklare (Ulrike Schnaas).

\section{BAKGRUND OCH SYFTE}

Boken beskriver och reflekterar över ett tvåårigt universitetsövergripande partnerskapsprojekt som engagerat både studenter och personal vid Uppsala universitet. Syftet med boken beskrivs vara att inspirera dem som vill utforska nya sätt att lära för att kunna utveckla en bättre utbildning genom att utmana konventionella undervisningsformer och möjligheter för lärande. Boken är även tänkt att vara ett erbjudande till läsarna att själva bidra med sina tankar och erfarenheter, något som beskrivs närmare nedan.

\section{UTGÅNGSPUNKTER}

Boktiteln talar tydligt om vilken typ av innehåll och utgångspunkter läsaren har att vänta sig, nämligen ett stöd till hur man kan arbeta med att utveckla ett studentaktivt deltagande i högre utbildning. Boken vilar på ett kunskapsteoretiskt grundantagande som innebär att lärande ses som ett gemensamt äventyr som studenter, lärare och andra har ett gemensamt ansvar för. Ord som delaktighet, partnerskap, inkludering löper som en röd tråd genom boken.

Att vara delaktig $\mathrm{i}$ ett partnerskap innebär att skapa något tillsammans (co-creation). Ett sådant partnerskap bygger på en öppenhet för deltagarnas olika perspektiv, erfarenheter och röster och att använda sig av dessa för att kunna lära tillsammans, både studenter och lärare. Denna

*Författarkontakt: gun.sparrhoff@liu.se

Artiklar och reflektioner är kollegialt granskade. Övriga bidragstyper granskas av redaktionen. Se www.hogreutbildning.se ISSN 2000-7558

(C)2019 Gun Sparrhoff. This is an Open Access article distributed under the terms of the Creative Commons Attribution-NonCommercial 4.0 International License (https://creativecommons.org/licenses/by-nc/4.0/), allowing third parties to share their work (copy, distribute, transmit) and to adapt it, under the condition that the authors are given credit, that the work is not used for commercial purposes, and that in the event of reuse or distribution, the terms of this license are made clear.

Citation: Gun Sparrhoff (2019) "Bokrecension: An Active Student Participation Companion», Högre utbildning, 9(2), 29-31. http://dx.doi org/10.23865/hu.v7.1734 
typ av lärande utmanar det traditionella sättet att organisera och genomföra högre utbildning. I stället för att läraren och dennes förmedling av ett förutbestämt kunskapsstoff står i fokus görs även studenten ansvarig för sitt lärande och aktiva deltagande i utbildningen. Detta innebär nya roller för både utbildare och studenter, något som ställer nya krav på en ny typ av lärande för alla inblandade. I boken framhålls behovet av ett så kallat transformativt lärande. Det innebär en transformering av såväl den som lär i termer av personlig utveckling och emancipation som en transformering av synen på kunskap. Transformativt lärande innebär ett mer kritiskt och aktivt förhållningssätt som utmanar maktrelationer, auktoritet och ägarskap av kunskap genom att utmana våra förgivettagna referenspunkter, vanor och tankemodeller. En kritisk reflektion uppmuntras därför som ett sätt att synliggöra och ta hänsyn till olika typer av etiska dimensioner utifrån de olika parternas perspektiv.

Att arbeta och lära i denna typ av partnerskap kan vara utmanande för såväl studenter som utbildare. Det finns heller inga färdiga modeller och mallar för hur detta ska gå till i praktiken. Dessa behöver skapas i samverkan mellan de parter som ingår i partnerskapet.

\section{INNEHÅLL OCH UPPLÄGG}

Boken består av tre delar: I) Orient yourself, 2) Get started - equipment and maps for safe travels, 3) Dig deeper - exploring research, theory \& the purpose of education. Den som förväntar sig ett traditionellt upplägg med en tydlig innehållsförteckning kommer att bli besviken. Upplägget ligger dock helt i linje med bokens idé. Läsaren ges en Reader's guide genom de tre delarna med hjälp av en illustration som liknar en spelplan där vägen mellan bokens hållpunkter är markerad med en streckad linje.

Innehållsligt erbjuder boken såväl teorier om deltagande, kollaboration, transformativt lärande mm. som olika erfarenheter av partnerskapsprojektet och en verktygslåda med praktiska verktyg. Därtill finns en mängd länkar till olika typer av media som fördjupar och exemplifierar innehållet. Läsaren bjuds även in som aktiv medskapare genom plats för att rita egna kartor, reflektera, ta bort, lägga till och klottra.

\section{BIDRAG}

Författarna sammanfattar sina slutsatser med att konstatera att det rollskifte som pågår inom högre utbildning i termer av förändrad syn på vad det innebär att vara student, lärare etc. skapar nya spännande utrymmen och förutsättningar för undervisning och lärande. För den som vill börja arbeta med partnerskap delar de med sig av sina erfarenheter utifrån det tvååriga partnerskapsprojektet vid Uppsala universitet i ett antal punkter:

- Det behövs en koordinerande funktion för ASP inom den enhet som ansvarar för akademiskt lärarskap (t.ex. högskolepedagogiskt centrum) för att stödja studenter och utbildare genom övning, seminarier, konsultationer och utbyte av erfarenheter. Enheten har ansvar för att utvärdera och följa upp rutiner. Partnerskapet bör utökas med samarbete med ett flertal aktörer, t.ex. studentorganisationer och bibliotek.

- Särskilda ekonomiska medel behöver avsättas för ASP.

- Involvera studenter från flera olika fakulteter och ämnen.

- Arbete med ASP borde vara en del av universitetens meritsystem för lärare.

I min läsning av boken har jag pendlat i tankarna mellan mina olika funktioner och roller inom universitetsvärlden, som lektor i pedagogik, studierektor, kursansvarig lärare på grund- och 
avancerad nivå, pedagogisk utvecklare vid en högskolepedagogisk enhet, forskare och som tidigare student, doktorand och studievägledare. Från alla dessa positioner ser jag stora möjligheter med ASP. Om vi på allvar menar att högre utbildning ska förbereda studenter för dagens och morgondagens föränderliga (arbets)liv (ja, jag menar båda!) räcker det inte med att lära dem ett antal förutbestämda kunskaper. Det räcker inte heller att likt en papegoja tala om Studentcentrerat lärande (SCL) och som utbildare anta ett curlinglärarskap där vi sopar banan för studenterna, vilket i och för sig sätter studenten i centrum men utan att de görs aktiva och ansvariga för sin utbildning. Bokens fokus på det gemensamma partnerskapet och det gemensamma ansvaret för lärandet kommer att bli nödvändigt i ett ständigt föränderligt samhälle där vi måste tänka i nya banor och lära oss att involvera många olika perspektiv och erfarenheter.

Som utbildare behöver jag i alla mina olika roller, tillsammans med såväl studenter, kollegor, andra funktioner vid universitetet som partners utanför universitetet, samverka för att hitta former för att möjliggöra och iscensätta ett aktivt och kollaborativt partnerskap som baseras på ett både kritiskt och kreativt förhållningssätt. En nyckelfunktion för förändring i denna riktning är den verksamhet som bedrivs vid de högskolepedagogiska enheterna vid universiteten. Dessa enheter kan bidra till att utmana traditionella synsätt på kunskap, studenters lärande och inte sällan oreflekterade modeller för undervisning och i stället samverka med studenter och andra partners för att tillsammans utveckla nya former för det akademiska lärarskapet i syfte att stödja studenters lärande och utveckling. Här ser jag ett viktigt och angeläget användningsområde för denna bok. Genom att erbjuda såväl teorier, erfarenheter som praktiska verktyg gör boken verkligen skäl för sin ambition att vara en följeslagare. 